\title{
Immigration and Internal Migration "Flight": A California Case Study ${ }^{1}$
}

\author{
William H. Frey
}

The University of Michigan

\begin{abstract}
Recent analyses of 1990 census migration data have pointed up disparities in the way immigration and internal migration contributions affect an area's demographic profile. They show that there is little overlap between states with large population gains from internal migration from other parts of the United States and states with large population gains from immigration from abroad. This emerging pattern, along with the fact that immigration and internal migration select on very different demographic characteristics, could lead toward a "demographic balkanization" of the nation's population. This paper evaluates immigration-induced out-movement from California, based on an analysis of recently released migration data from the 1990 U.S. census. The results presented here suggest that California's out-migration consists of two different migration systems: first, an immigration-induced "flight" that exports lower income and less-educated Californians, primarily, to the nearby states of Washington, Oregon, Nevada and Arizona. And second, a more conventional migration exchange with the rest of the United States that involves the redistribution of better educated, higher income migrants. It is the former migration system which appears to be most responsive to the low-skilled immigration flows, while the latter should be responsive to more conventional labor market employment characteristics. This implies that, irrespective of changing economic conditions in the state, the continued immigration of low-skilled migrants will lead to more losses of native-born internal migrants to neighboring states and metropolitan areas. However, these migrant streams will not be made up of the "best and brightest" residents that characterize most conventional migration streams.
\end{abstract}

'A longer version of this report with more extensive background statistics is Research Report 94-306 (Frey, 1994b) available from Publications, Population Studies Center, The University of Michigan, Ann Arbor, Ml 48104.

Please address correspondence to Dr. Frey at the Population Studies Center, 1225 South University Avenue, Ann Arbor, MI 48104-2590.

Population and Environment: A Journal of Interdisciplinary Studies

Volume 16, Number 4, March 1995

(c) 1995 Human Sciences Press, Inc. 


\section{INTRODUCTION}

Recent U.S. migration studies have pointed up disparities in the way immigration and internal migration contributions affect an area's demographic profile. They show that there is little overlap between states with large population gains from internal migration from other parts of the United States and states with large population gains from immigration from abroad. This emerging pattern, along with the fact that immigration and internal migration select on very different demographic characteristics, may be leading toward a demographic "balkanization" of the nation's population (Frey, 1995).

If this scenario is valid, then it is important to focus attention on those states and metropolitan areas that serve as "ports-of-entry" for the continuing sharply directed immigration waves (Fix \& Passel, 1994). These areas receive disproportionate numbers of immigrants dominated by minorities and lower skilled workers that will significantly affect their population and labor force compositions (Borjas \& Freeman, 1992).

Just as important is the unique internal migration "flight" response, now evident in these states, that does not share the demographic selectivity patterns of usual long-distance migration within the United States (Frey, $1993 ; 1994 a)$. In contrast to conventional long-distance migration patterns which select on the most educated, professional members of the labor force responding to a national labor market (Long, 1988), the new immigration-induced flight appears to select on poverty and working class households as well as persons with less than college educations. It is likely that this flight represents a response to competition from immigrants competing for low-skilled service and manufacturing jobs, to the housing cost squeeze on middle income households, and probably to some aversion to the new racial and ethnic diversity on the part of many whites (Tilove \& Hallinan, 1993; and results from earlier studies of 1980 census statistics in Filer, 1992; Walker, Ellis \& Barff, 1992; White \& Imai, 1993). However, little is known about the nature of this immigration-induced internal migration which holds important implications for demographic change in "high immigration states."

This paper seeks to understand the nature of this immigration-induced flight in a case study of California, based on an analysis of recently released migration data from the 1990 U.S. census. The results presented here suggest that California's out-migration consists of two different migration systems: first, an immigration-induced flight that exports lower income and less-educated Californians, primarily, to the nearby states of Washington, Oregon, Nevada and Arizona. And second, a more conventional mi- 
WILLIAM H. FREY

gration exchange with the rest of the United States that involves the exchange of better educated, higher income migrants. It is the former migration system which appears to be most responsive to the low-skilled immigration flows, while the latter should be responsive to more conventional labor market employment characteristics. This implies that, irrespective of changing economic conditions in the state, the continued immigration of low-skilled migrants will lead to more losses of native-born internal migrants to neighboring states and metropolitan areas. However, these migrant streams will not be made up of the "best and brightest" residents that characterize most conventional migration streams

In addition to focussing on California's interstate migration exchange, the paper also evaluates the impact of these streams on the populations of nearby states, and presents further information on internal migration dynamics for metropolitan areas and counties within California. The data in this paper are derived from both a $5 \%$ sample and the full $16.7 \%$ migration tabulation of the 1990 census. These tabulations draw from the census question on "residence 5 years ago" and pertain to migration over the $1985-90$ period. They represent the most current migration data that provide detailed social and demographic characteristics for migrants at the state and county level. Nonetheless, the reader should be aware that the census enumeration significantly understates the illegal immigrant population (Fix \& Passel, 1994; Center for Immigration Studies, 1994).

\section{MIGRATION DYNAMICS AND DEMOGRAPHIC SELECTIVITY}

Before discussing the California case study, it is useful to review earlier findings which link a state's dominant migration dynamics with the demographic selectivity associated with migration. (See Frey 1993; 1994a for a fuller discussion). The significant distinction here is whether a state's dominant migration flow is comprised of immigration from abroad or internal migration from other states. To clarify this distinction, a typology of states is presented based on their dominant migration sources of change. (See Figure 1 and Table 1).

States classed as "high immigration states" include the six states with largest 1985-90 migration from abroad, where the immigration component overwhelms net internal migration (California, New York, Texas, New Jersey, Illinois, Massachusetts). Each of these states tends to have large existing settlements of earlier immigrants from Latin America and Asia. The six states classed as "high internal migration states" (Florida, Georgia, North Carolina, Virginia, Washington, Arizona) displayed greatest net increases 


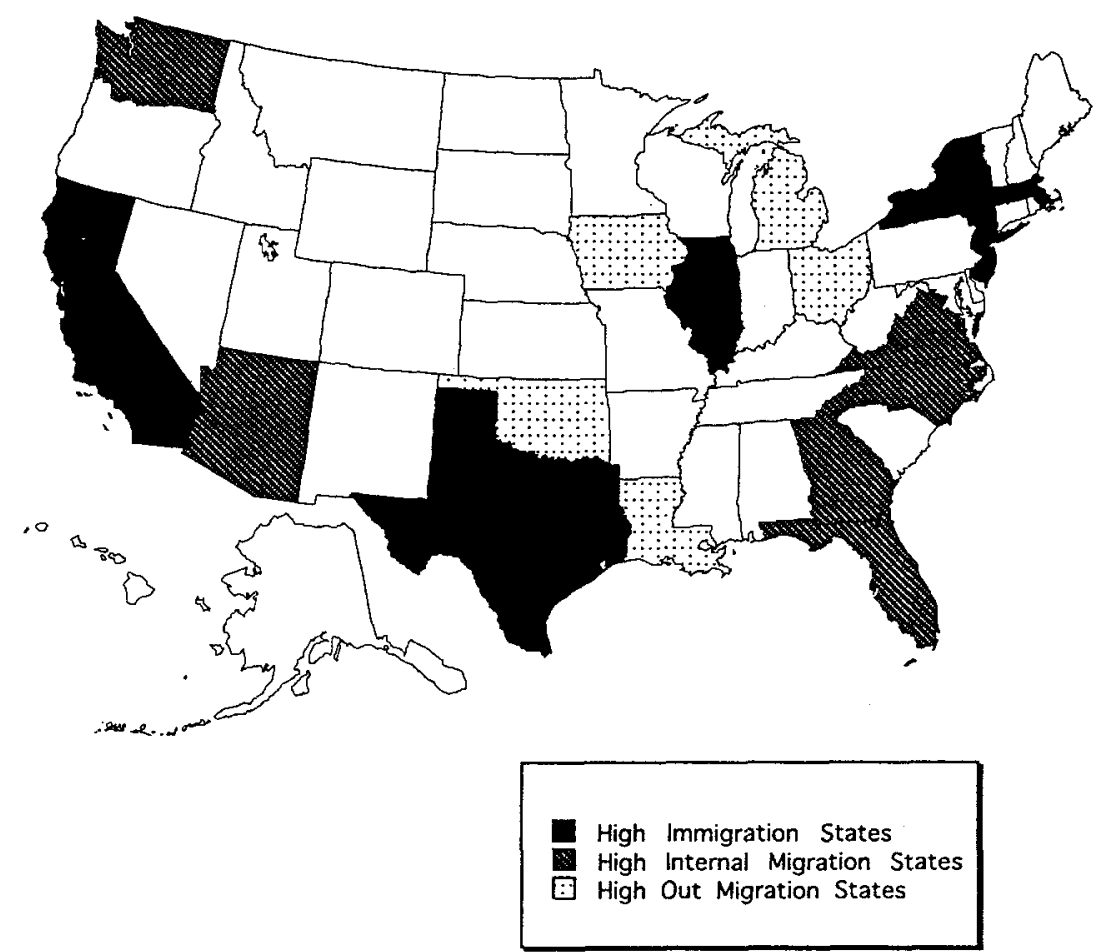

FIGURE 1. A migration classification of states.

in their migration exchanges with other states over the 1985-90 period. Moreover, in each case, these internal migration gains significantly exceeded those of the immigration component. (This is the case for Florida, as well, despite its strong attraction for immigrants.) These internal migration magnets are located, largely, in the South Atlantic and the Pacific and Mountain regions. Their allure lies with their growing economies and, in most cases, climatic and other amenities. Finally, a third class of states include five "high out-migration states" — Louisiana, Michigan, Ohio, Oklahoma and lowa. These states displayed greatest net out-migration in their exchanges with other States and were not recipients of large immigration from abroad.

One clear distinction in migration selectivity involves the contrast of minority-white majority compositions of inflows to high immigration states versus those to high internal migration states. That is, the dominant immigration stream to the former states is comprised, largely, of minorities from Latin American or Asian origins-while the internal migrant gains to the 
WILLIAM H. FREY

TABLE 1

\section{Classification of States by Dominant Immigration and Interstate Migration Contributions to Population Change, 1985-90}

\begin{tabular}{|c|c|c|c|}
\hline \multirow[b]{2}{*}{ Rank } & \multirow[b]{2}{*}{ State } & \multicolumn{2}{|c|}{ Contribution to $1985-90$ Change (1000s) } \\
\hline & & Migration from Abroad & $\begin{array}{l}\text { Net Interstate } \\
\text { Migration** }\end{array}$ \\
\hline \multicolumn{4}{|c|}{ I HIGH IMMIGRATION STATESa } \\
\hline 1 & California & 1499 & 174 \\
\hline 2 & New York & 614 & -821 \\
\hline 3 & Texas & 368 & -331 \\
\hline 4 & New Jersey & 211 & -194 \\
\hline 5 & Illinois & 203 & -342 \\
\hline 6 & Massachusetts & 156 & -97 \\
\hline \multicolumn{4}{|c|}{ "I HICH INTERNAL MICRATION STATES } \\
\hline 1 & Florida & 390 & 1071 \\
\hline 2 & Georgia & 92 & 303 \\
\hline 3 & North Carolina & 66 & 281 \\
\hline 4 & Virginia & 149 & 228 \\
\hline 5 & Washington & 102 & 216 \\
\hline 6 & Arizona & 80 & 216 \\
\hline \multicolumn{4}{|c|}{ III HIGH OUT-MIGRATION STATES' } \\
\hline 1 & Louisiana & 20 & -251 \\
\hline 2 & Ohio & 69 & -141 \\
\hline 3 & Michigan & 74 & -133 \\
\hline 4 & Oklahoma & 32 & -128 \\
\hline 5 & lowa & 17 & -94 \\
\hline
\end{tabular}

Source: Compiled from 1990 Census files at the Population Studies Center, The University of Michigan.

* 1990 State residents who resided abroad in 1985.

**1985-90 In-migrants from other States minus 1985-90 Out-migrants to other States.

aStates with largest 1985-90 migration from abroad which exceeds net interstate migration.

bStates with largest 1985-90 net interstate migration and exceeds migration from abroad.

¿States with largest negative net interstate migration and not recipients of large migration from abroad.

Source: William H. Frey, "The New White Flight." American Demographics, April, 1994.

latter states are made up of mostly native-born whites (and, in some cases, blacks ${ }^{2}$ ). By themselves, these different processes will lead to wider disparities in the racial compositions between these two categories of states.

This article focuses on another distinction that exists across state cate-

\footnotetext{
${ }^{2}$ Nearly one-third of internal migrants to Georgia are black.
} 
gories. This involves the unique demographic selectivity of internal migration from high immigration states, a process that differs from the more typical selectivity between gaining and losing states. The latter, more traditional interstate migration can be characterized as a "circulation of elites" which disproportionately selects on higher income, better educated and professional migrants. Under this process, gaining states tend to increase their ranks in these categories, while losing states show disproportionate losses among these more valued demographic groups.

This traditional process still characterizes movement into the high internal migration states, and movement out of the high out-migration states. The data in Table 2 show that in the two high internal migration statesGeorgia and Washington-1985-90 net migration gains are greatest among college graduates and lowest among high school dropouts and persons in poverty. The opposite of this process occurs in the two high outmigration states, Louisiana and lowa. Here, net out-migration is greatest among college graduates and least likely among high school dropouts and persons in poverty.

This typical situation is not the case for 1985-90 internal migration from the two high immigration states shown in Table 2. In both California and New Jersey, greatest out-migration occurs for persons with less than college educations and for their poverty populations. Moreover, in both states, there is a net in-migration of college graduates. In these high immigration states there appears to be a link between immigration and internal out-migration at the lower end of the socioeconomic spectrum. Among other implications of this linkage, is a sharp change in the minority-majority composition of the less educated, and lower income populations of these states. (California's less-than-high school population and poverty population are already an majority/minority). The in-migration of more educated persons is also inconsistent with typical patterns, and reflects the operation of "dual economies" in these high immigration states (Mollenkopf \& Castells, 1991). In order to understand the nature of these emerging internal migration processes, the remainder of the paper focuses on California as a case study.

\section{CALIFORNIA MIGRATION-TWO SEPARATE SYSTEMS}

The overall contributions of immigration from abroad and net internal migration from other states to California's population can be seen in the first two columns of Table 3. It is clear that over the 1985-90 period, immigration dominates the state's population gains in almost all demographic 


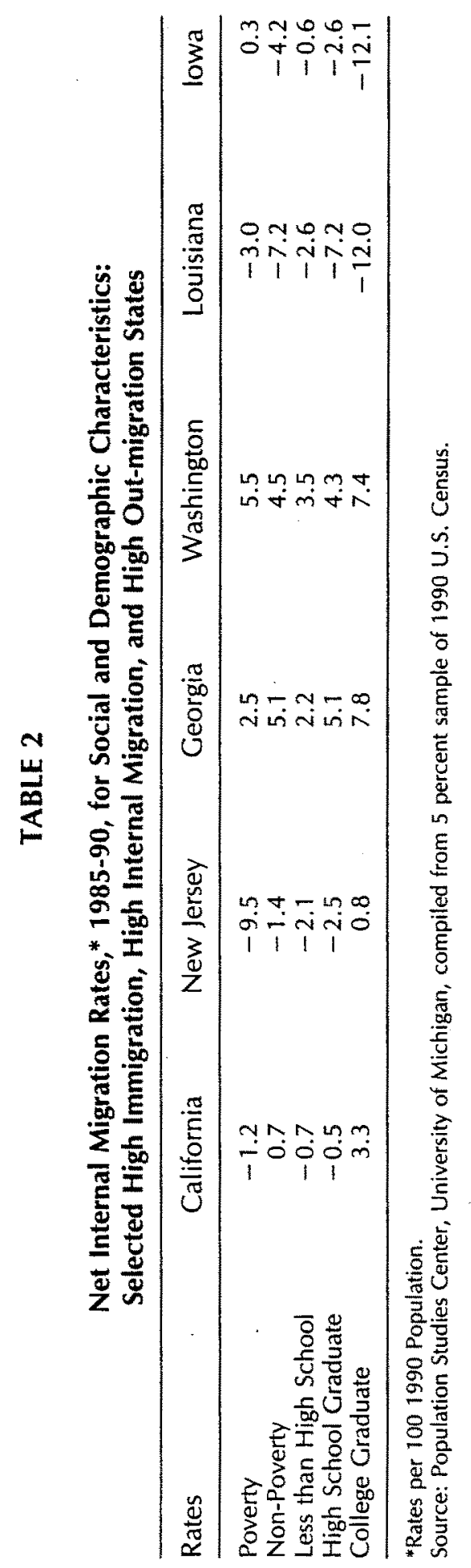


POPULATION AND ENVIRONMENT

TABLE 3

Rates of Immigration and Net Internal Migration for California by Selected Social and Demographic Characteristics*

\begin{tabular}{|c|c|c|c|c|}
\hline & \multirow[b]{2}{*}{$\begin{array}{l}\text { Immigration } \\
\text { from Abroad }\end{array}$} & \multirow[b]{2}{*}{$\begin{array}{l}\text { Net Internal } \\
\text { Migration }\end{array}$} & \multicolumn{2}{|c|}{ Net Internal Migration } \\
\hline & & & $\begin{array}{c}\text { With Nearby } \\
\text { States** }\end{array}$ & $\begin{array}{c}\text { With Rest } \\
\text { of U.S. }\end{array}$ \\
\hline Total & 5.5 & 0.6 & -0.7 & 1.3 \\
\hline \multicolumn{5}{|l|}{ Race/Latino Status } \\
\hline Non-Latino Whites & 1.7 & 0.7 & -0.9 & 1.6 \\
\hline Blacks & 1.8 & 1.0 & -0.4 & 1.4 \\
\hline Asians & 14.4 & 2.3 & 0.0 & 2.3 \\
\hline Latinos & 9.9 & -0.1 & -0.4 & 0.2 \\
\hline \multicolumn{5}{|l|}{ Ages } \\
\hline 5 to 14 & 35.4 & -1.0 & -5.0 & 3.9 \\
\hline 15 to 24 & 9.3 & 2.7 & -0.1 & 2.8 \\
\hline 25 to 34 & 6.8 & 1.8 & -0.6 & 2.4 \\
\hline 35 to 44 & 3.9 & 0.4 & -0.7 & 1.0 \\
\hline 45 to 54 & 7.5 & -0.1 & -1.6 & 1.5 \\
\hline 55 to 64 & 2.5 & -1.5 & -1.4 & -0.1 \\
\hline $65+$ & 1.6 & -1.1 & -1.2 & 0.1 \\
\hline \multicolumn{5}{|c|}{ Poverty Status for Persons } \\
\hline Below Poverty & 12.4 & -1.2 & -1.1 & -0.1 \\
\hline Above Poverty & 4.1 & 0.7 & -0.6 & 1.4 \\
\hline \multicolumn{5}{|l|}{ Household Income } \\
\hline Below $\$ 5,000$ & 9.9 & -4.7 & -1.8 & -2.9 \\
\hline$\$ 5-10,000$ & 5.0 & -2.8 & -1.6 & -1.2 \\
\hline$\$ 10-15,000$ & 6.9 & -3.3 & -2.0 & -1.3 \\
\hline$\$ 15-25,000$ & 7.1 & -2.0 & -1.6 & -0.3 \\
\hline$\$ 25-35,000$ & 6.4 & -0.4 & -1.2 & 0.7 \\
\hline$\$ 35-50,000$ & 5.6 & 1.3 & -0.6 & 1.9 \\
\hline$\$ 50-75,000$ & 4.7 & 3.1 & 0.1 & 3.0 \\
\hline$\$ 75,000+$ & 3.9 & 4.1 & 0.3 & 3.8 \\
\hline \multicolumn{5}{|l|}{ Education } \\
\hline Less than HS & 7.3 & -0.7 & -0.8 & 0.1 \\
\hline HS Grad & 2.9 & -0.5 & -1.1 & 0.5 \\
\hline Coll Grad & 4.4 & 3.3 & -0.4 & 3.7 \\
\hline
\end{tabular}

*Rates per 1001990 Population.

**Washington, Oregon, Nevada and Arizona.

Source: Population Studies Center, University of Michigan, compiled from 5 percent sample of 1990 U.S. Census. 
WILLIAM H. FREY

categories. Yet, the greatest immigration gains (when expressed as rates per 1001990 population) accrued to California's poverty population, its lowest income households, and persons with less than high school educations. As well, immigration contributes substantially to the state's younger, Asian and Latino population.

The net internal migration, however, reflects almost the mirror image of these patterns. Among internal migrants, those in poverty, with low incomes, and lesser education exhibit a net out-migration from the state. It is also noteworthy that while immigrants contribute substantially to California's child population, internal migrants with children are more apt to leave than move into the state. Still another important demographic group, among net out-migrants, is the older, retiree population. And among race and ethnic groups, only Asians show substantial net in-migration from other states, when expressed as a rate per 1001990 population.

These net internal migration patterns camouflage two very different migration systems. One of these reflects California's migration exchanges with its nearby states-Washington, Oregon, Nevada and Arizona. The other encompasses migration streams between California and the rest of the country. The former system is unique in two respects: First, it accounts for most of the net out-migration of Californians to other states. And second, it is largely responsible for the "mirror image" selectivity of internal out-migration from the state, in response to the large immigrant flows.

These patterns are made plain in the third and fourth columns, Table 3 , and in Figure 2. When California's net internal migration is decomposed into the migration exchange with nearby states (Washington, Oregon, Nevada and Arizona), and the exchange with the rest of the United States, one finds California losing 190,000 migrants in the former exchange, while it gains 363,000 migrants with the latter. In its exchange with each nearby state, California lost 59,000 migrants to Nevada, 55,000 to Washington, 48,000 to Oregon and 27,000 to Arizona. While these net losses occurred for a broad array of social and demographic categories, they were especially selective among poverty, low income and less educated migrants, among households with children, elderly migrants, and whites. The only categories of California's population which did not show a net out-migration with these nearby states were high income households and Asianseach of which showed only a minimal net in-migration over the 1985-90 period.

By contrast, net in-migration to California from the rest of the United States is positive for most sociodemographic categories but particularly among those with highest incomes, the best educations, and among youn- 
POPULATION AND ENVIRONMENT
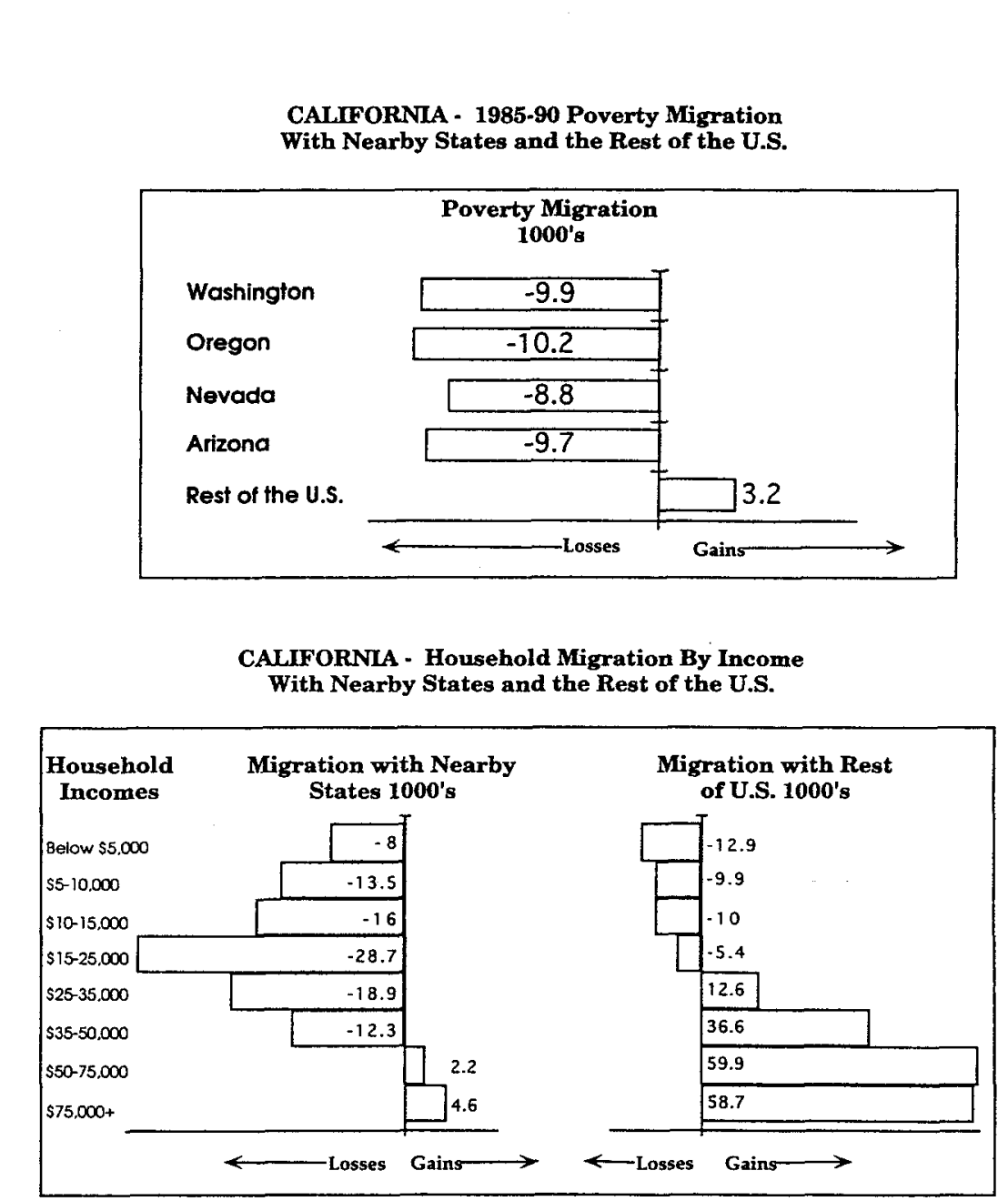

FIGURE 2. Migration exchanges between California and nearby states, and the rest of the U.S.

Source: William Frey, University of Michigan from 1990 U.S. Census

ger people, especially those with children. The contrast between these migration exchanges and those with nearby states are particularly striking on measures of education and household income. While the latter exchange led to an exporting of 145,000 Californians with less than college educations, the former exchange brought into the state 160,000 college graduates from nonnearby states. Similarly, while California exported 85,000 
WILLIAM H. FREY

households with incomes under $\$ 35,000$ to its neighboring States, it imported over 100,000 households with incomes of over $\$ 50,000$ in its exchanges with the rest of the country.

The first migration system-between California and its nearby statesrepresents a spreading out of low and middle income households, often with children, which have greater demographic similarities to immigrants to California than to internal-migrants from other states. These out-migrants appear to be responding to competition for jobs, housing, and perhaps the increased social costs associated with immigration that are less problematic in neighboring states. What is unusual is the "spreading out" nature of this migration which is essentially long distance migration to neighboring states. Typically, long distance migration responds to specific "pulls" associated with economic opportunities, amenities, or family and friendship ties. This migration system, between California and its neighboring region, is clearly responding to "push" factors in California.

The second migration system-between California and the rest of the country-is much more typical. It is selective among those demographic groups which participate in a nation-wide labor market and, at least during the 1985-90 period, found a demand for their skills in the professional ranks or in knowledge-based industries in the dynamic economies of Los Angeles, San Francisco and their environs. Although some segments of the immigrant population are also highly skilled, their relative numbers are small; so immigration does not pose the same competition for well-educated migrants from other states that it does for high school graduates or dropouts. It is quite likely that the post- 1990 period with its recessions and defense industry cutbacks has reduced the demand for these well-educated migrants associated with California's "second" migration system (Bolton, 1993a; 1993b). Yet, unlike the migrants in the "first" migration systemwith nearby states-these more traditional migrants are likely to reemerge when California's economy again picks up because they are less affected by the continued immigrant flows.

It should be pointed out that while California experiences a net loss in its exchanges with nearby states, its exchange patterns are mixed with other States in the United States (see Figure 3). Among these remaining 46 (including the District of Columbia), 31 send more migrants to California than they get back. Still, the losses that California incurs to other nonnearby states are relatively small in comparison to their losses with Washington, Oregon, Nevada, and Arizona. Significant losses (greater than 5,000 out-migrants) are only incurred with Florida, Virginia, Georgia, North Carolina, and Tennessee-all in the nation's booming South Atlantic region.

Among states from which California gains in migration exchanges, 

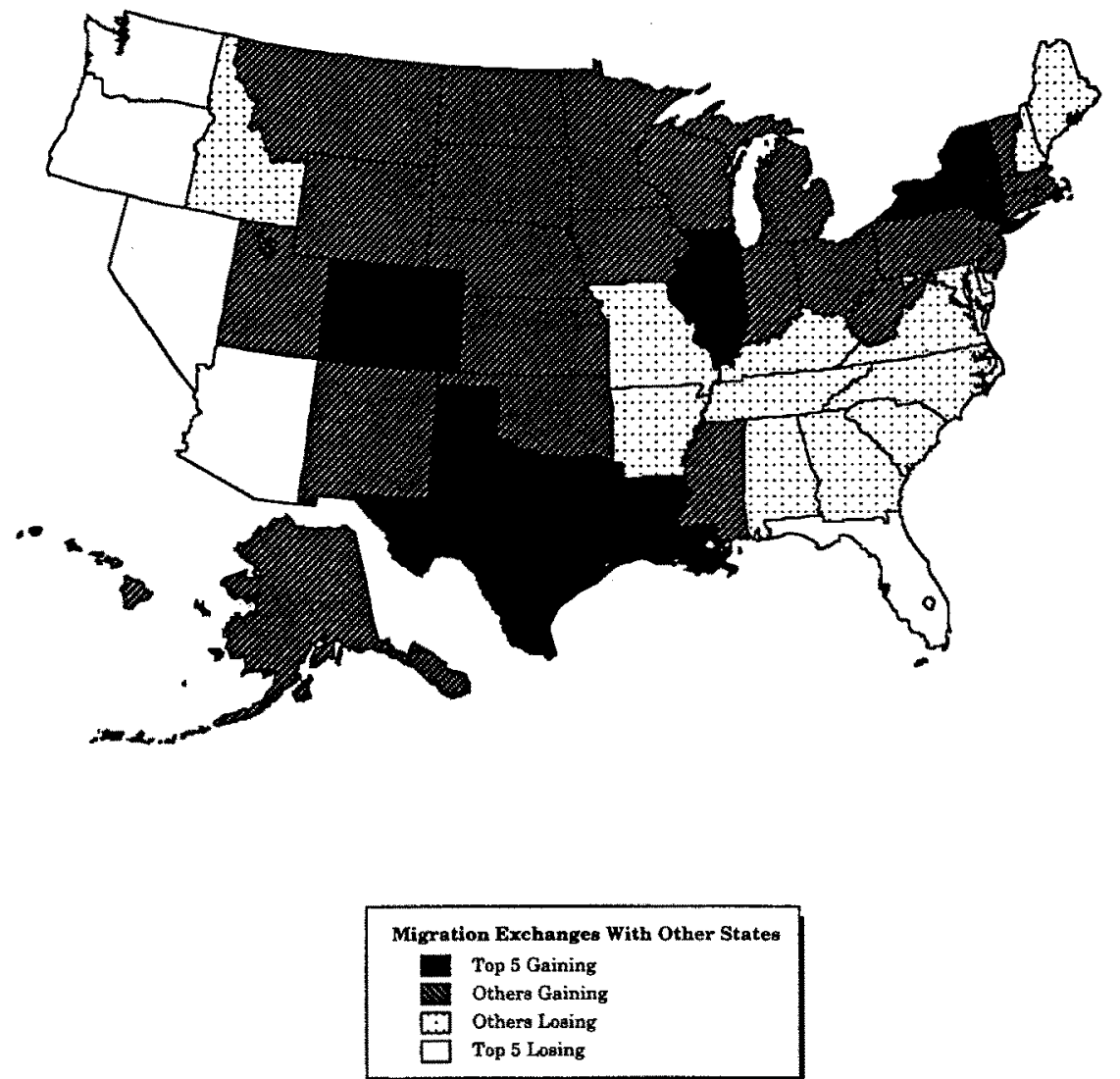

FIGURE 3. States from which California is gaining and losing migrants.

Texas, New York and Illinois dominate as major "senders." While all three States are high immigration states, they also experienced economic slowdowns during the late 1980s (especially Texas). Colorado, Louisiana, Michigan and New Jersey are also dominant senders of migrants to California. Colorado sent especially large numbers of whites, high school, and college graduates over the $1985-90$ period.

\section{IMPACTS ON NEARBY STATES}

In light of California's unique migration relationship with its nearby states, the question can be raised: How did California's out-migrants affect 
WILLIAM H. FREY

demographic change in Washington, Oregon, Nevada, and Arizona? This is significant because, as has been shown, these migration exchanges are not selective on the "best and brightest" of California's resident population.

Although each of California's four neighboring states is also affected by immigration from abroad, they are affected much more substantially by internal migration. In Arizona, Washington and Oregon, the growth due to internal migration is 2-3 times as high as that due to immigration. It is more than 5 times as high in Nevada, which increased its population by over $15 \%$ as a result of $1985-90$ internal migration from other states. Internal migration plays a different role in these four states than it does for California. In California, internal migration serves as a vehicle for exporting lower-skilled and low income migrants to other states, partially alleviating the much greater gain in numbers contributed by the dominant, immigration component. In each of the other four states, internal migration dominates immigration in all categories-including gains in their poverty populations, college dropout and high school graduate populations.

The unique migration relationship between California and its nearby states prompts the following question: To what extent do California's migration exports affect overall net migration gains in Washington, Oregon, Nevada and Arizona? And do California's contributions substantially increase gains in these states' poverty and low-skilled populations? The data in Table 4 provide some answers by showing the relative contributions from exchanges with California and exchanges with the rest of the United States in each state's net migration gains for the 1985-90 period. Overall, California's exchanges had their greatest impact on Oregon, accounting for $58 \%$ of the State's net migration gains. This is attributable, in part, to Oregon's weaker economy during this period and, therefore, its smaller draw of migrants from the nationwide pool. Nonetheless, California accounted for $34 \%$ of the net gains in Nevada, $27 \%$ of those in Washington, and $11 \%$ in Arizona.

Despite these variations in overall contributions, California's exports make significant and, in some cases, overwhelming contributions to nearby states' poverty, unskilled, and elderly migration gains. Californians account for $62 \%$ of Nevada's poverty migration gains and $56 \%$ of Oregon's over the 1985-90 period. They also account for well over one-third of such gains in Arizona and Washington. In all four states, California contributions account for substantially greater shares of high school dropout and high school graduate migration gains than is the case for college graduates. (Arizona actually loses college graduates in its exchange with California). Hence, the relatively similar levels of gains, across education categories, that were displayed by these states overall, are the result of: gains in less-skilled and poverty migrants in exchanges from California, and 


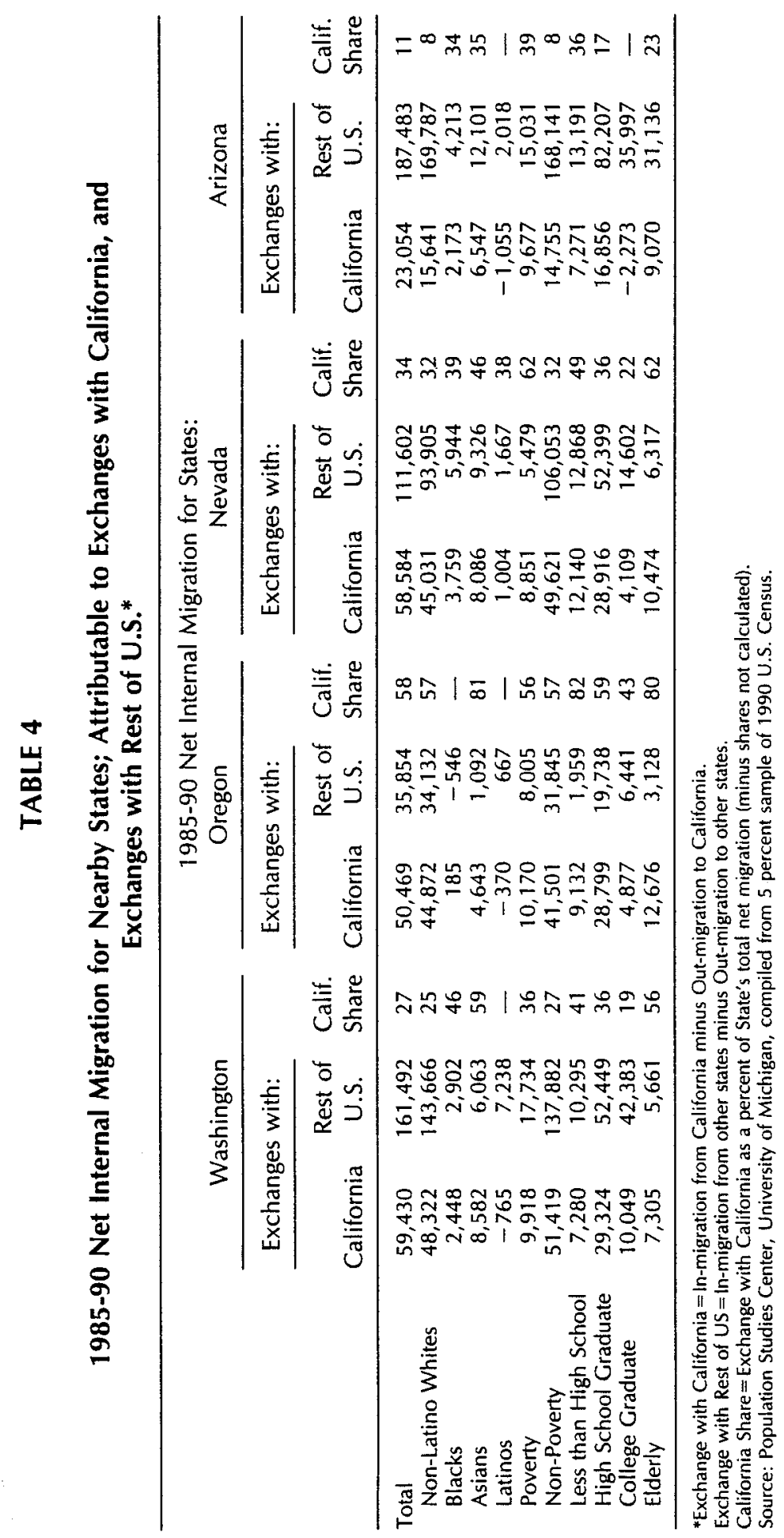


WILLIAM H. FREY

gains in college graduate and higher income migrants in exchanges from other parts of the country.

Finally, it is clear that the elderly out-flow from California has spilled over into these surrounding states and contributed, substantially, to their elderly population gains. Eighty percent of Oregon's elderly migration gains, $62 \%$ of Nevada's, and $56 \%$ of Washington's are attributable to California's elderly exports. The share is smaller-23\% - for Arizona, which serves as a national magnet for retirees.

\section{IMMIGRATION AND INTERNAL MIGRATION WITHIN CALIFORNIA}

While immigration-internal migration dynamics are plainly at work in California's exchanges with neighboring states, these linkages also exist for redistribution within California. Immigration is not distributed uniformly across the state's metropolitan areas and counties, but is sharply focused on a few port-of-entry areas. This is evident from the list of California metropolitan areas, shown in Table 5. The lion's share of 1985-90 immigrants from abroad focussed predominantly on two CMSAs, Los Angeles and San Francisco-Oakland. Both of these exhibit a substantial net out-migration of internal migrants to other California and out-of-state destinations. Nearby major metropolitan areas, San Diego and Sacramento, receive the next greatest number of immigrants, but also capture the greatest numeric gains in internal migrants, among the state's metropolitan areas. Some of the these may be spillover migrants from Los Angeles and San Francisco, but these areas also constitute magnets for migrants from other parts of the country. Some other metropolitan areas show large percentages of internal migration increases. These include the central region metro areas of Modesto and Stockton as well as the smaller northern MSAs, Chico and Redding.

Table 6 focuses, specifically, on the selectivity of migration for selected metropolitan areas. Of interest here is the contrast in internal migration selectivity between the high immigration metros, Los Angeles and San Francisco-Oakland, on the one hand, and that for San Diego and Sacramento, on the other. The selectivity patterns for the former two areas are exaggerated versions of the California state-wide patterns, discussed above. That is, for both areas there is an accentuated net out-migration of the poverty population, as well as for the elderly population, but an inmigration of college graduates.

Both Sacramento and San Diego stand in contrast to these two larger 
TABLE 5

Immigration and Internal Migration Components of 1985-90 Population Change. Metro Areas, California and Vicinity

\begin{tabular}{|c|c|c|c|c|}
\hline \multirow[b]{2}{*}{ Region/Metro Area* } & \multicolumn{2}{|c|}{$\begin{array}{l}\text { Migration Components } \\
\qquad\left(1000^{\prime} \mathrm{s}\right)\end{array}$} & \multicolumn{2}{|c|}{$\begin{array}{c}\text { Rates per } 1001990 \\
\text { Population }\end{array}$} \\
\hline & $\begin{array}{l}\text { Immigration } \\
\text { from Abroad }\end{array}$ & $\begin{array}{l}\text { Net Internal } \\
\text { Migration }\end{array}$ & $\begin{array}{l}\text { Immigration } \\
\text { from Abroad }\end{array}$ & $\begin{array}{c}\text { Net Internal } \\
\text { Migration }\end{array}$ \\
\hline \multicolumn{5}{|l|}{ Northern Region } \\
\hline San Francisco CMSA & 293,306 & $-103,498$ & 5.0 & -1.8 \\
\hline Sacramento MSA & 36,380 & 117,732 & 2.7 & 8.6 \\
\hline Yuba City MSA & 5,161 & 2,407 & 4.6 & 2.2 \\
\hline Chico MSA & 2,777 & 17,740 & 1.6 & 10.4 \\
\hline Redding MSA & 716 & 11,223 & 0.5 & 8.3 \\
\hline \multicolumn{5}{|l|}{ Central Region } \\
\hline Stockton MSA & 14,282 & 23,254 & 3.3 & 5.3 \\
\hline Modesto MSA & 9,035 & 35,328 & 2.7 & 10.5 \\
\hline Merced MSA & 8,437 & 2,949 & 5.3 & 1.8 \\
\hline Fresno MSA & 26,394 & 9,249 & 4.4 & 1.5 \\
\hline Visalia-T_P MSA & 11,162 & 7,703 & 3.9 & 2.7 \\
\hline Bakersfield MSA & 15,206 & 12,960 & 3.1 & 2.6 \\
\hline Salinas-S-M MSA & 20,290 & 1,731 & 6.3 & 0.5 \\
\hline Santa Barbara MSA & 16,204 & -584 & 4.7 & -0.2 \\
\hline \multicolumn{5}{|l|}{ Southern Region } \\
\hline Los Angeles CMSA & 899,007 & $-174,673$ & 6.7 & -1.3 \\
\hline San Diego MSA & 115,847 & 126,855 & 5.0 & 5.5 \\
\hline \multicolumn{5}{|l|}{ Nevada and Arizona } \\
\hline Reno MSA & 6,727 & 16,311 & 2.9 & 6.9 \\
\hline Las Vegas MSA & 20,551 & 128,680 & 3.0 & 18.8 \\
\hline Phoenix MSA & 43,861 & 139,678 & 2.2 & 7.2 \\
\hline
\end{tabular}

*Metro Areas defined as of June 30, 1990. Abbreviated names are used.

Source: Population Studies Center, University of Michigan, compiled from full migration sample of 1990 U.S. census.

port-of-entry metros. Both gain internal migrants in all sociodemographic categories but Sacramento appears to pick up more spillover migration with its higher gains in the poverty and less-than-college graduate populations. San Diego's gains are less likely to come from these groups, while the metro attracts significant gains in college graduates.

A more comprehensive view of these immigration-internal migration dynamics can be gained from an examination of county-level changes. These data are displayed in Figures 4 and 5, based on a more detailed analysis. These data point up nuances which were not apparent with the metropolitan area-wide data. One of these patterns is the high rates of internal migration growth for nonmetropolitan counties in the Northern Re- 


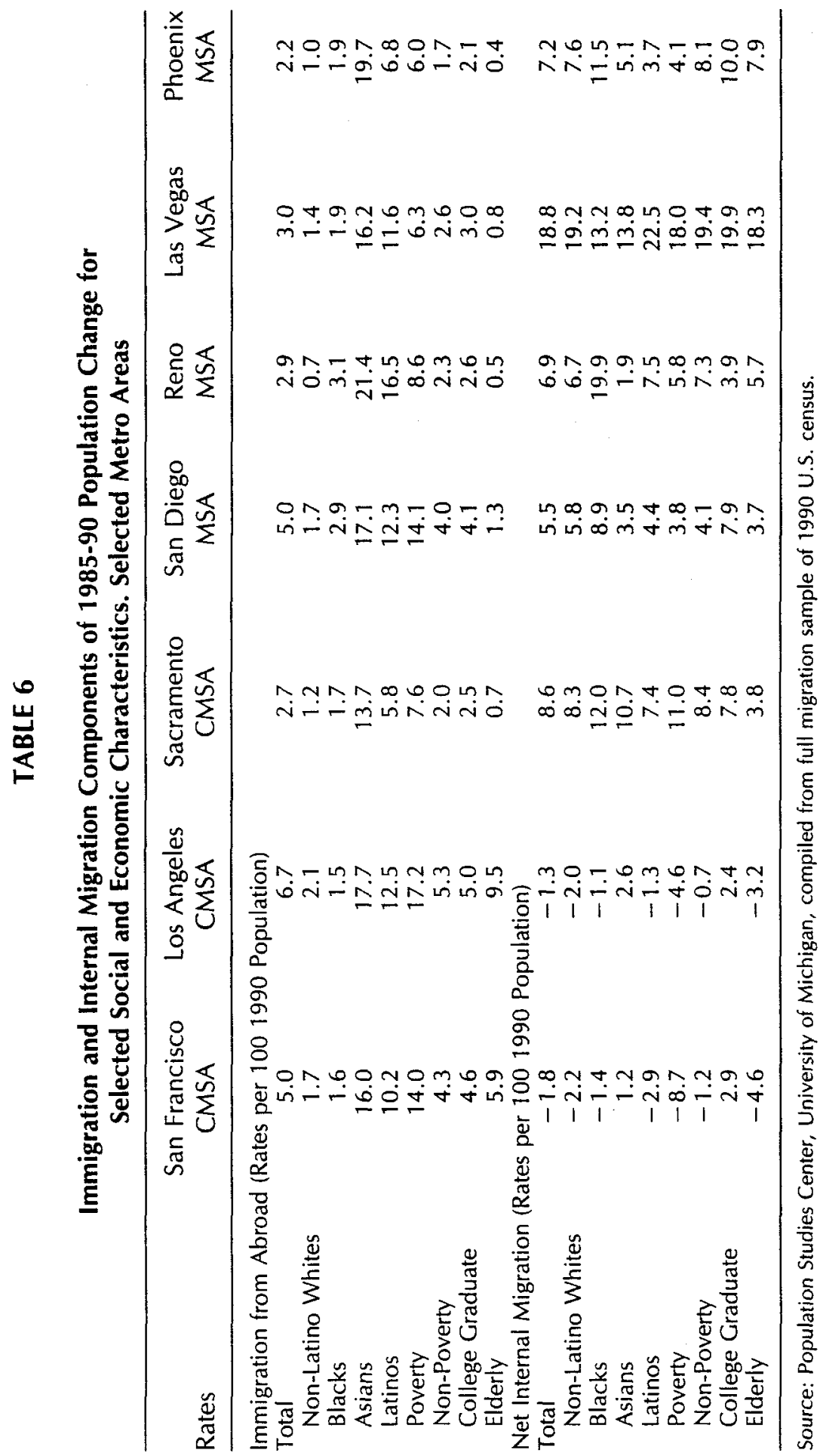




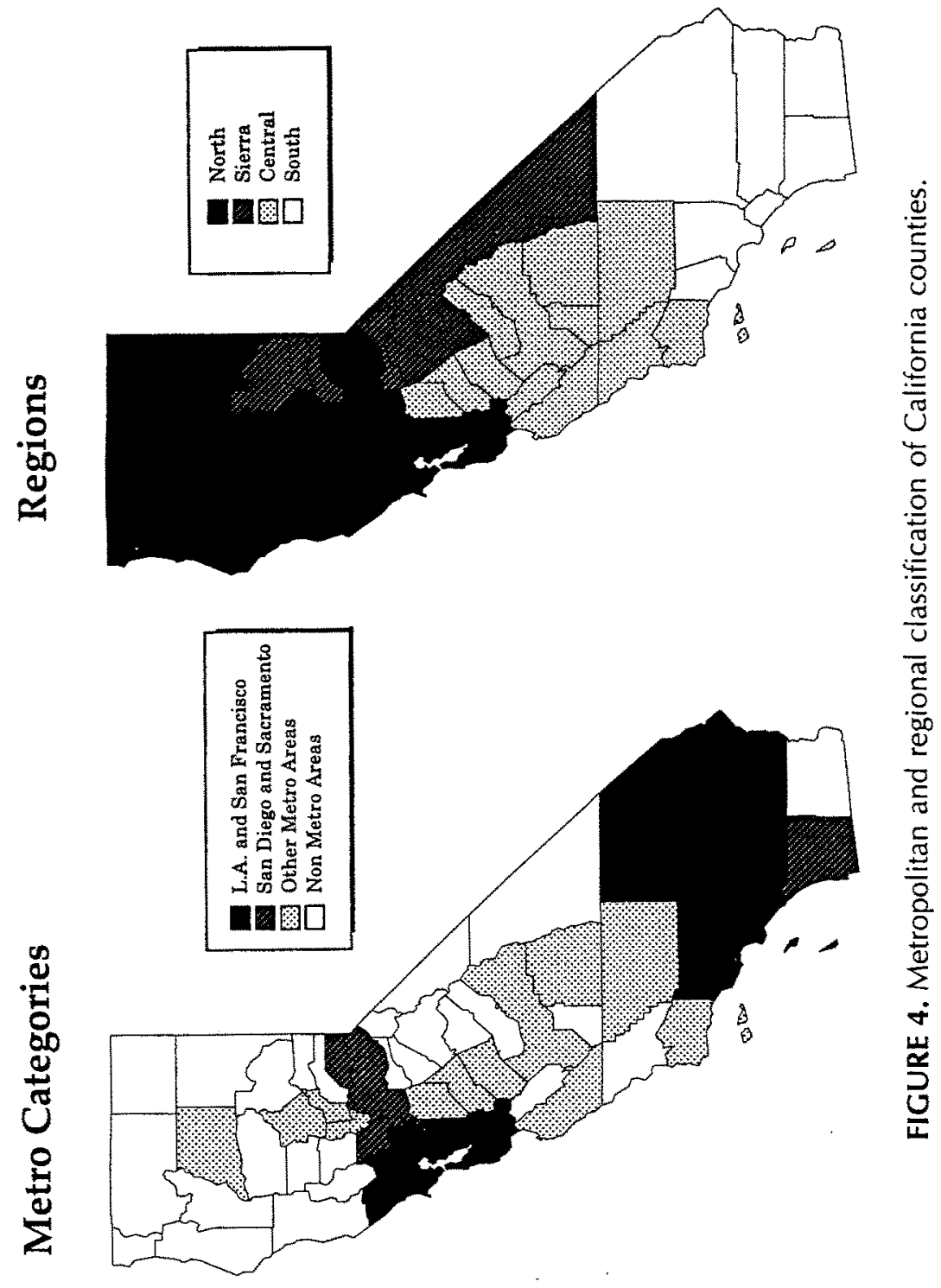




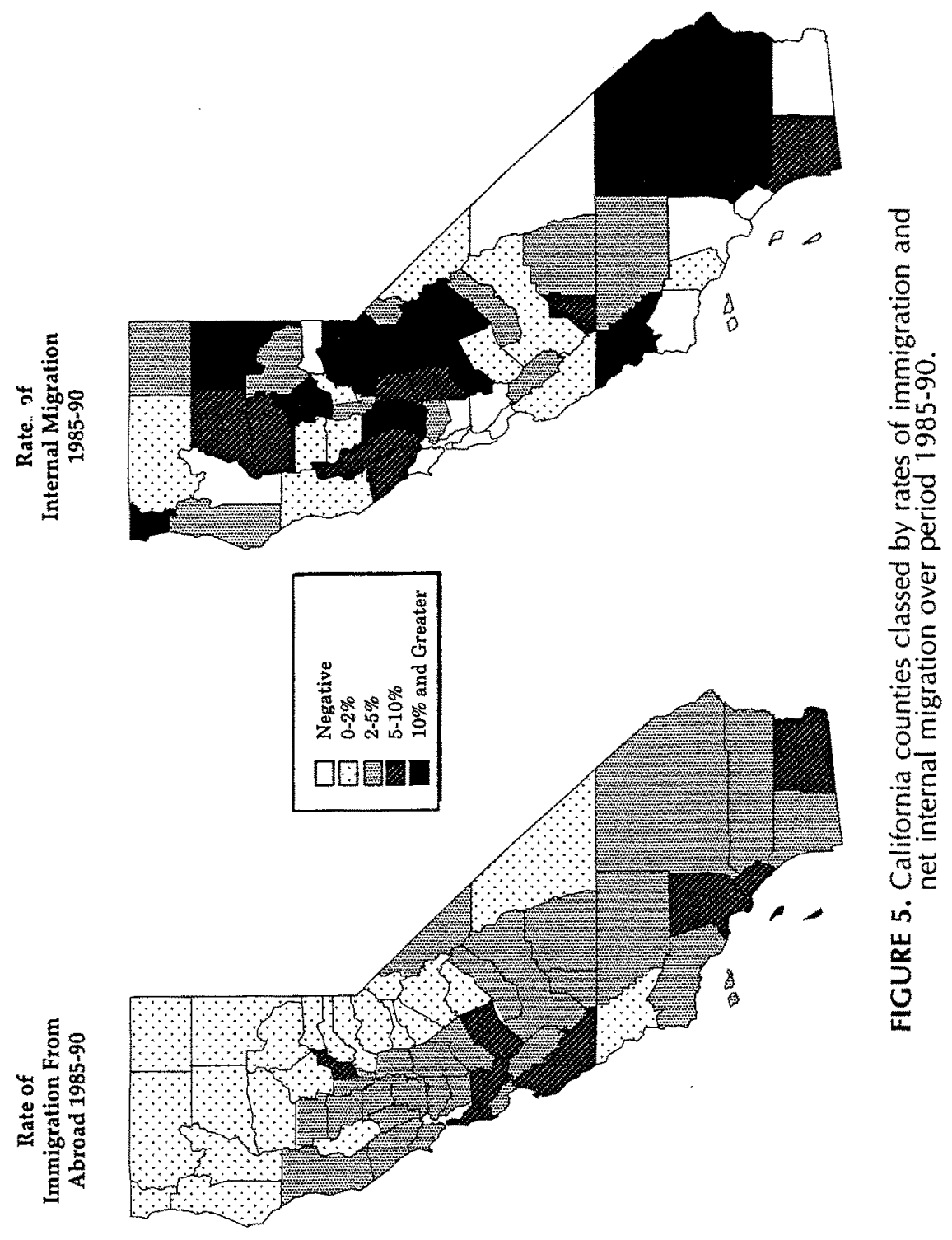


POPULATION AND ENVIRONMENT

TABLE 7

Zero-order Correlations Between Measures of Migration from Abroad and Internal Migration 1985-90 for California Counties

\begin{tabular}{lcc}
\hline & \multicolumn{2}{c}{$\begin{array}{c}\text { Correlations with Immigration from } \\
\text { Abroad }\end{array}$} \\
\cline { 2 - 3 } $\begin{array}{l}\text { Internal Migration } \\
\text { for Population }\end{array}$ & $\begin{array}{c}\text { Number } \\
\text { of Migrants }\end{array}$ & $\begin{array}{c}\text { Migration } \\
\text { Rates }^{2}\end{array}$ \\
\hline Total & $-.79^{*}$ & $-.54^{*}$ \\
Poverty & $-.88^{*}$ & $-.39^{*}$ \\
Non-poverty & $-.77^{*}$ & $-.49^{*}$ \\
College Grad & -.17 & -.23 \\
Age 65+ & $-.89^{*}$ & $-.44^{*}$ \\
(N) & $(58)$ & $(58)$ \\
\hline
\end{tabular}

*Significant at .05 level.

aate per 1001990 population.

gion, in the Sierra Foothills, and in the Central Region. The Sierra Foothills' nonmetropolitan counties are particularly attractive to the elderly retirement-aged population.

Overall, there does appear to be a relationship between migration from abroad and internal migration even across the 58 counties of California. This is apparent from a view of the Figures as well as from the data presented in Table 7. Here, zero-order correlations are calculated between immigration from abroad and internal migration specific to various social and demographic groups. When based on the total numbers of immigrants and internal migrants (column 1), it is clear that there is a significant negative relationship between a county's immigration from abroad and its net internal migration for several population subgroups. The correlation is somewhat stronger for the net out-migration of the poverty population and the elderly than for other demographic categories. In fact, the negative relationship is not statistically significant at the .05 level for college graduates. When these correlations are based on rates rather than total numbers (column 2), a similar result is obtained. Again, the negative correlation between immigration and college graduate net migration is not statistically significant.

\section{CONCLUSION}

This article reviews the findings from a case study of California's internal migration with the rest of the United States based on 1990 census data. 
WILLIAM H. FREY

Because it demonstrates the existence of distinct immigration-within US migration dynamics, we plan to conduct similar studies of other high immigration states. The California case points up the existence of two separate migration systems. The first system involves migration exchanges between California and its nearby states as well as across counties and metropolitan areas within the state. This pattern shows a negative relationship between immigration from abroad and net internal migration which is most pronounced for low income, lesser skilled and elderly migrants. The exportation of these migrant groups from California to neighboring states contributes appreciably to these states' migration gains in poverty, lesseducated, and elderly populations. This internal migration system is unique because of its apparent push impetus from immigration, because it selects on lower rather higher sociodemographic characteristics, and because of its spatial limitation, which is circumscribed by states and metropolitan areas in close proximity to the area of origin.

The second migration system appears to be operating as a more conventional exchange between California and other parts of the country. The migrants participating in this redistribution process are selective on college graduates, upper income households, and professionals who are participating in a nationwide job market. Their movement to California during the 1985-90 period reflects the relatively good economy of the state during the late 1980s. Unlike the migrants in the first system, these migrants are less hindered by competition with the large numbers of less skilled immigrants flowing into the State.

This assessment of California's migration patterns suggests that the first migration system is most responsive to the size and composition of immigration into California, while the second migration system is most responsive to the state of the economy as it affects the employment prospects of professionals and highly skilled workers in knowledge-based industries. The post-1990 recessions and defense cutbacks slowed or reversed California's gains for the migrants in the second, nation-wide migration system. Yet, these migration streams should be expected to rebound with reversals in the state's economic fortunes. However, the out-migration associated with the first system seems to respond more closely to competition with immigrants for jobs, housing, and perhaps some uneasiness at the increasing diversity in the state. The fact that this movement was in place prior to California's more recent economic woes suggests an immigration-internal migration connection, with both economic and cultural foundations, which is less responsive to cyclical or recessionary trends.

The immigration-internal migration relationship documented here for California will be investigated more thoroughly in the other large port-ofentry states. Available evidence from the 1990 census suggests that this 
relationship does exist in these high immigration states (Frey, 1994a; 1994c), indicating a relocation of their low-skilled, low and middle income residents to other regions of the country. What needs to be established is how closely this relationship is tied to the sociodemographic composition of immigration flows, as well as to their sizes. The composition of immigrant flows is affected by both the preference system of the Immigration Act of 1990-which places a high priority on family reunification, and by characteristics of illegal immigrants (Fix \& Passel, 1994). To the extent that this selective internal out-migration does persist in concert with continued high immigration levels to these port-of-entry states, these states' demographic and labor force profiles in terms of race, ethnicity, age and class structure will increasingly diverge from other parts of the country. What this California case study emphasizes is that recent immigration-induced out-migration is not just local relocation. It is much broader in its geographic scope and involves movement out of entire labor markets, metropolitan areas and states.

\section{REFERENCES}

Bolton, Nancy (March, 1990). Migration: Stirring the kettle in California. UCLA Business Forecast.

Bolton, Nancy (December, 1991). Migration revisited. UCLA Business Forecast.

Bolton, Nancy (March, 1993a). Immigration, migration and the labor force of California. UCLA Business Forecast.

Bolton, Nancy (June, 1993b). The redistribution of California's population. UCLA Business Forecast.

Borjas, George J. \& Freeman, Richard (1992). Immigration and the work force. Chicago: University of Chicago Press.

Filer, Randall K. (1992). The effect of immigrant arrivals on migratory patterns of native workers. In George \}. Borjas and Richard B. Freeman (Eds.). Immigration and the work force, pp. 245-270. Chicago: University of Chicago Press.

Fix, Michael \& Passel, Jeffrey (1994). Immigration and immigrants' setting the record straight. Washington, DC: The Urban Institute.

Frey, William H. (1993). Inter-state migration and immigration for whites and minorities, 1985-90: The emergence of multi-ethnic states. Research Report No. 93-297. Ann Arbor, MI: Population Studies Center, University of Michigan.

Frey, William H. (April, 1994a). The new white flight. American Demographics, 40-48.

Frey, William H. (1994b). Immigration and internal migration: 1990 census findings for California. Research Report No. 94-306. Ann Arbor, Ml: Population Studies Center, University of Michigan.

Frey, William H. (1994c). Immigration and internal migration "flight" from U.S. metro areas: 1990 census findings by race, poverty and education. Research Report No. 94-304. Ann Arbor, MI: Population Studies Center, University of Michigan.

Frey, William H. (1995). The new geography of US population shifts: Trends toward balkanization. In Reynolds Farley (Ed.). The state of the union in the 1990s' social trends. New York: Russell Sage. 
WILLIAM H. FREY

Long, Larry (1988). Migration and residential mobility in the United States. New York: Russell Sage.

Johnson, James H., Jr. \& Roseman, Curt C. (1990). Increasing black out-migration from Los Angeles: The role of household dynamics and kinship systems. Annals of the Association of American Geographers, 80, 205-222.

Mollenkopf, John H. \& Castells, Manuel Eds. (1991). Dual city: Restructuring New York. New York: Russell Sage.

Tilove, Jonathan \& Hallinan Joe (August 8, 1993). Whites flee immigrants: Flee white states. Newark Star Ledger, p. 1.

Walker, Richard, Ellis, Mark \& Barff, Richard (1992). Linked migration systems: Immigration and internal labor in the United States. Economic Geography, 68, 234-248.

White, Michael \}. \& Imai, Yoshie (1993). The impact of immigration upon internal migration. Population and Environment, 15(3), 189-209. 